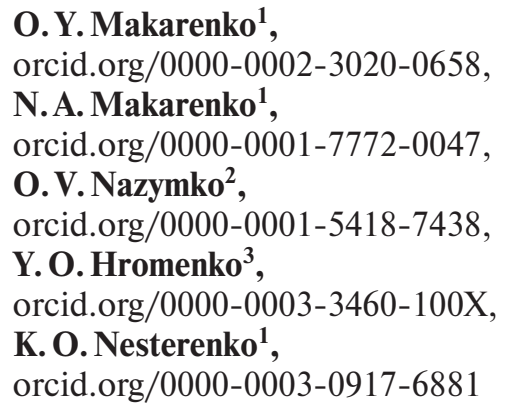

1 - Donetsk Law Institute of the Ministry of Internal Affairs of Ukraine, Kryvyi Rih, Ukraine, e-mail: a.y.makarenko@ gmail.com

2 - Volodymyr Dahl East Ukrainian National University, Severodonetsk, Ukraine

3 - Odesa State University of Internal Affairs, Odesa, Ukraine

\title{
PROBLEMATIC ISSUES OF CRIMINAL PROSECUTION FOR THE ILLEGAL EXTRACTION OF MINERAL RESOURCES
}

Purpose. To research the criminalization of offences against illegal extraction of minerals of strategic importance; it is of equal importance for legislative and law enforcement activities, development and implementation of economic programs, and the strengthening of the government and local authorities.

Methodology. The research focuses on identifying vulnerabilities of prosecution for illegal mining by means of studying and analyzing the legal framework of Ukraine, theoretical foundation in relevant fields, analysis of judicial practice of bringing persons to justice under Art. 240, Paragraph 2 of the Criminal Code of Ukraine. Systems of special approaches and methods, namely the formal-logical, logical-normative, method of system analysis facilitated investigation of the declared subject.

Findings. Certain problems are revealed which occur during the formation of penal prohibition of the studied criminal practices at the legislative level, including the inconsistency of criminalization of illicit mining with the severity of negative legal consequences.

Originality. The article analyzes the problematic issues of prosecution for illegal extraction of minerals under Article 240, Paragraph 2 of the Criminal Code of Ukraine "Violation of the established rules for the use of subsoil, if it has created a threat to life, health or the environment, as well as illegal extraction of minerals of public importance". Proposals are substantiated aimed at enhancing the current criminal legislation and its implementation by law enforcement agencies of Ukraine in dealing with illegal exploitation of natural resources of national importance.

Practical value. The work studied the norms of legal liability for illicit subsurface use, and judicial practice of law enforcement of the specified norms. The authors maintain that the legal provisions of criminal legislation which provides for liability for this act mentioned, should be significantly improved in terms of clear defining of the disposition and broadening and strengthening of the sanction on Article 240, Paragraph 2 of the Criminal Code of Ukraine. The expediency is confirmed to expand the category of perpetrators under this article considering the involvement of a wide range of people both directly in the process of illegal mining, and further transportation and sale.

Keywords: minerals, mining, responsibility, the Criminal Code of Ukraine, sanction, disposition, law enforcement agencies, local authorities

Introduction. The land, mineral resources, atmospheric air, water, and other natural resources located within the territory of Ukraine, as well as natural resources of the Ukrainian continental shelf, exclusive (maritime) economic zone are the objects of property rights of the Ukrainian people. Rights of ownership are exercised on behalf of the Ukrainian people by the State and local authorities within the limits set down by the Constitution [1].

The territory of modern Ukraine is rich in a significant number and variety of minerals; proceeding from their diversity and location in different regions of the state, the environmental offences and crimes have their own factual, law, and geographical specific context and relevant consequent effects of their commitment. Accordingly, illegal forest devastation (the crime in the area of forest utilization) as well as mining of amber are more prevalent in western regions; concurrently, central and eastern areas are feeling the pressure of other environmental crimes such as illegitimate underground and openpit mining of mineral resources, unlawful extraction of hydrocarbons (there are corresponding mining activities in Kharkiv and Poltava regions, and they are mainly carried out by stateowned companies), pollution of soil, water resources and atmospheric air.

Problems of land use are a separate topic for research in the fields of the land market regulation and land use intrinsic to open-pit mining, prevailing at industrial central and eastern

(C) Makarenko O.Y., Makarenko N.A., Nazymko O. V., Hromenko Y.O., Nesterenko K.O., 2021 regions of Ukraine, and South of the Autonomous Republic of Crimea.

Furthermore, in Ukraine, there has been a total absence of any statistics in the context of latency of the environmental crimes, the volume of the illegally extracted resources as well as information on economic losses of budgets of different levels, data on the redundant or uncreated job opportunities, and also the death toll in illegal mineral production, the analysis of economic and legal consequences for particular regions and the entire country, information on the temporarily occupied territories of Donetsk, Luhansk regions, and the Autonomous Republic of Crimea.

Even if some scientists are interested in the latency of crimes, the latency of environmental offenses is poorly researched; dissertations have not been defended for the last ten years, scientific studies in the relevant field are not published, with few exceptions. The system of training specialists in the areas of environment, engineering, including law enforcement officers has changed fundamentally; the existing system of training specialists in the field of prevention (district police officer) and patrol police (who are not obliged to have legal education at all according to the current legislation) also receives mixed reviews.

Challenging issues of training professional investigators in prosecuting the crimes, effective managers and specialists of local self-government authorities training, whose purpose is to provide administrative services for land registration and permissions, required for the extraction of minerals have remained unresolved. The State government bodies created to 
regulate relevant public relations and provide assistance in gathering evidence and stopping illegal actions by subsoil users (for example, the State Labor Service of Ukraine) have been almost destroyed or they are in extremely unsatisfactory material and technical condition with insufficient staffing.

Existing gaps in the legislation, which allow for the extraction of minerals with impunity (including strategic importance) are unacceptable as they lead to deregulation and abolishing of the institutions of the State in the light of the general decline of the economy, negative consequences of the global Covid-19 pandemic, underfunding of budgets of various levels, first of all, local ones, increasing of medical spending.

Literature review. The scholars H. I. Baliuk, L. O. Bondar, N. S. Havrysh, R. S. Kirin, Yu. S. Shemshuchenko, I. M. Koziakov, M.V. Krasnova have contributed to scientific research on relevant topics from the perspective of environmental law. The problems of quality of law enforcement agencies work during the investigation of ecological crimes have been studied by O. M. Bandurka, V.P.Bakhina, A.F. Volobuieva, V.H.Honcharenko, V.A.Zhuravel, O.A. Kyrychenko, N.I. Klymenko, O. N. Kolesnychenko, V. O. Konovalova, I. I. Kotiuk, V. K. Lysychenko; certain types of environmental crimes have been investigated by V. V. Yehoshyna, Yu. H. Korukhova, A. Ye. Merkurisova, A. P. Rezvan, M. V. Sverdiukova, M. O. Selivanova.

The authors of this research, as well as the scientists in different domains of interest, have already studied some legal and organizational aspects of increasing level of environmental safety by the subjects of subsoil use, monitoring of the geological environment and mineral resources of Ukraine [2], legal liability in general, the improvement of administrative and criminal liability for illegal mining, advancing of procedural mechanisms for the use of legal norms [3, 4], the latency of the environmental crimes. It confirms the relevance and versatility of the topic in today's conditions while all this is further corroborated by research in the relevant sectoral areas taking into account the specifics of particular minerals [5].

It should be noted that a significant number of research studies have been devoted to this topic. They consider crimes in the field of illegitimate exploitation of minerals, land relations, corruption crimes related to the seizure of natural objects (woods, lands, minerals), the aspects of environmental policy and environmental law, and their impact on other spheres of ensuring environmental security in the European Union $[6,7]$. There are a number of large cross-sectional studies devoted to advancing Natural Resources Law, protection and improvement of natural resources $[8,9]$, and also to the settlement of environmental relations via the institutions of civil law, which should minimize the participation of the state in certain legal relations due to a mechanism of the "contract".

From there, the concerns associated with the use of natural resources, including their extraction, are manifested in completely different legal relationships. Activities of both lawabiding subsoil users and those who extract minerals illegally or have a special permit (or other consent documents) but carry out extraction in larger quantities or commit other offenses have an impact not only on public relations in law enforcement but also in the field of economics, construction, and the existence of institutions of state power, local authorities, ecology, and mining. Therefore, it requires a kind of intellectual regulation that should solve technical, environmental, and legal concerns.

Unsolved aspects of the problem. The purpose of regulation of any social relations, including those relating to the extraction of minerals, is to comply with the requirements of environmental legislation (other legal norms governing labor, economic and civil relations) and to develop a coherent system in which the relations between subjects [10] of law will be settled by means of certain regulators (rules of law) also in order to prevent harm to both private and public interests.

Regulation of relations associated with the legitimate use of natural resources (comprising extraction of mineral re- sources) by adopting relevant laws and rules, establishing and operating relevant bodies which are to provide for implementation of the state, local or sectoral policies control, will not be effective without the implementation of a protective mechanism, that is a feasible and workable tool for prosecuting offenders and dishonest subsoil users, and setting up a preventive effect in order to reduce the number of persons wishing to violate the legislation requirements in the field of subsoil use via strengthening and guaranteeing the inevitable punishment.

When carrying out the scientific research, the authors determined the period of fifteen years for the analysis of the sentences imposed by the District Court of Kryvyi Rih in Dnipropetrovsk region, viz. from 2005 to 2020 and analyzed the criminal cases referred to the District Court of Kryvyi Rih in Dnipropetrovsk region which were qualified according to Part 2 Article 240 of the Criminal Code of Ukraine "Violation of the established rules of subsoil use, if it has created a threat to life, human health or the environment, as well as illegal extraction of minerals of national importance".

Based on the disposition of this article, it seems possible to make an in-depth analysis of environmental crimes committed in the industrial regions of Ukraine and of the effectiveness of the state policy both on the whole in respect of ensuring the right of citizens to a safe environment and in particular, having a realistic picture of the efficiency of the fight against crime in an industrial region of the city of Kryvyi Rih (which today is one of the powerful industrial centers of Ukraine, with more than significant contributions to the budgets of various levels).

As a result of the analysis of all criminal cases considered in the District Court of Kryvyi Rih in Dnipropetrovsk region for the period from 2005 to 2020 through the instrumentality of the information from the Unified State Register of Judicial Decisions, we have concluded that the existence of a mechanism for prosecuting persons who illegally extract minerals seems more than doubtful; and there is no possibility at all to determine the amount of minerals mined illegally, losses to the state and some sectors of the economy due to the lack of any appropriate government accounting mechanisms for all mineral deposits. Even the registration of such a natural object as land with its division into separate categories is problematic.

The issue of the presence or absence of violations of current legislation by large subsoil users operating in Kryvyi Rih has not been investigated at all within the scope of this work, as mining plants have special permits for the extraction of minerals, even with certain violations they are extremely difficult to identify and record (in part because of the staffed checkpoint at such enterprises). In this case, the violations can be recorded in another way (by means of primary documentation analysis in the verification of tax payments in full), and the acts are also criminalized by other articles.

The purpose of the study is to conduct the investigation of criminalization of infringements of illicit mining of mineral resources of strategic importance; its results are meaningful for both legislation and enforcement activities with consideration to the court practice on criminal proceedings considered by the District Court of Kryvyi Rih in Dnipropetrovsk region and provide the recommendations for improving the current legislation.

Taking into account the objectives we have determined the tasks of our study. They are:

- to carry out a comprehensive review and effectiveness analysis of the implementation of prosecution for illicit mining of mineral resources of public importance on the basis of current court practice;

- to analyze the legal and regulatory framework which works in current practice of prosecution for illicit mining of mineral resources of national importance;

- based on the analysis, to submit appropriate and effective proposals for the current legislation to improve the effectiveness of bringing the individuals to criminal responsibility for illicit mining of mineral resources, which should result in mit- 
igation (minimizing) of the harm caused to the state and the environment.

Methods. To research the complex issues relating to criminal liability for unlawful extraction of mineral resources of strategic importance we have studied and analyzed:

- Legislative Framework of Ukraine;

- theoretical research in appropriate fields of science;

- analysis of the court practice (on the example of the verdicts analysis considered by the District Court of Kryvyi Rih in Dnipropetrovsk region for the 15 years) in the domain of bringing the individuals to criminal responsibility qualified according to Part 2 Article 240 of the Criminal Code of Ukraine "Violation of the established rules of subsoil use, if it has created a threat to life, human health or the environment, as well as illegal extraction of minerals of national importance".

Results. Deliberate disregard of environmental regulations, standards, and requirements is the most pervasive violation in the area of environmental compliance. The breach of the relevant resolutions is conducive to the environmental risk and consequently to the existing danger of life, human health, or the environment. The offence of environmental safety is the type of environmental crime which might arise in violating ecological safety standards as a result of different economic activities. Taking into account the nature and degree of public danger, violations can be differentiated as minor offences (misdeeds) or crimes; according to the kinds of environmental abuses, the guilty persons may be subject to disciplinary, administrative, civil, and criminal liability [11].

Currently, persons engaged in illegal mining shall be prosecuted under Article 240 of the Criminal Code of Ukraine "Violation of the established rules of subsoil use" [12]. At the same time, the most challenging part of this article is the second one, which suggests that persons can be held liable for "violation of the established rules of subsoil use if it has created a threat to life, human health or the environment as well as illegal extraction of minerals of national importance".

The reason for the criminalization of this act is the relative prevalence of such illegal encroachments. However, if we analyze presumptive sanctions under Article 240, Paragraph 2 of the Criminal Code of Ukraine, they are more than symbolic and constitute a minor fine or restriction of liberty for up to three years of imprisonment for the same period. In the sanctions provided for by the Criminal Code of Ukraine, there is no risk of the crime instruments being confiscated (equipment, tools, vehicles), whereby minerals were extracted and exported. Other articles include no responsibility for the sale or acquisition of illegally mined minerals of public importance. In general, the above provides an occasion for, and in a rather complicated economic environment even "encourages" some individuals to commit more and more crimes and cause significant harm both to particular regions (in the form of revenue shortfalls to the budgets) and to the country as a whole.

In the light of the foregoing and the specifics of the commission of environmental crimes, to carry out the scientific research we selected Kryvorizkyi district in Dnipropetrovsk region (with an area of $1347 \mathrm{~km}^{2}$ ) as an example; because it is an independent administrative-territorial unit but at the same time is inextricably linked with the industrial city of Kryvyi Rih in whose territory there are five large industrial enterprises (Tsentralnyi, Pivnichnyi, Pivdennyi, Inhuletskyi Ore Mining, and Processing Industrial Complexes and "ArcelorMittal Kryvyi Rih"). These enterprises operate actually both inside and outside of Kryvyi Rih, in particular in Kryvorizkyi district (and in Shyrokivskyi district partially). To understand the situation on the land concerned, it is worth noting that: in Kryvorizkyi district there was the worst dynamics of the creation of unified territorial communities (UTC), and in comparison with other territorial units the speed and character of voluntary association of individual villages and settlements in the territorial communities were extremely low; it, in turn, re- sulted in the creation of several powerful UTCs, as well as extremely weak and geographically stretched ones.

The real problem of the inability to hold individuals accountable for illegal mining (minerals of national importance) or the inefficiency of the existing mechanism must be reaffirmed with a view to proposing amendments to the current legislation.

The mechanism for the protection of minerals of strategic importance exists in criminal legislation in a declarative way. Keeping in mind that one of the functions of the punishment is preventive activity, the robust analysis of the judicial practice in an individual industrial region (the District of Kryvyi Rih in Dnipropetrovsk region) has confirmed the ineffectiveness of existing mechanisms to bring the individuals to criminal responsibility for unlawful mining, and revealed the need to improve this or other valid legal acts immediately, along with other mechanisms that should protect the subsoil from illegal mining.

The existence of the judicial practice to prosecute persons who have committed criminal offences in the field of the environment, including those related to the illegal extraction of minerals of the state significance, in terms of the sentences imposed or entered into force is manifestly inadequate for declaring of the successful fight against environmental crimes; in turn, it has a very negative impact on the development of small and medium-sized enterprises and individual branches of the economy, underfunding of budgets of various levels, and actual funding of the criminality and the development of the offthe-books economy. The specific competitiveness between criminal and administrative legal norms makes the situation worse [13].

In this context, it is meaningful to point out the fact that as a result of the prosecution agencies reform, the procedural control over criminal environmental investigations (including illegal mining-related in Kryvyi Rih and the District of Kryvyi Rih) are carried out by the Prosecutor's Office No. 1; the specialized Environmental Protection Prosecutor's Office was liquidated as well as the structural unit in the form of the Prosecutor's Office of the District of Kryvyi Rih [14]; thus, according to the authors, it has a negative impact on the practical training of highly qualified specialists in narrow but important areas, which were previously the specialists of Environmental Prosecutor's Offices.

As regards the judicial reform [15], as a consequence of its incompleteness, the District Court of Kryvyi Rih in Dnipropetrovsk Region is continuing its work as a separate court carrying out legal proceedings on the consideration of the crimes committed on the territory of the District of Kryvyi Rih. Although in the practice of this Court the most interesting, in our opinion, is the judicial practice of considering cases involving offences covered by Article 240 of the Criminal Code of Ukraine "Violation of rules of protection of subsoil" [12].

According to the analyzed judicial practice for the period from 2005 to 2020, the District Court of Kryvyi Rih in Dnipropetrovsk region examined 9 criminal cases which resulted in convictions (according to the Unified State Register of Judicial Decisions); the charges were brought under Article 240, paragraph 2, of the Criminal Code of Ukraine. In this connection, it is important to note that in 2020 Article 240 was not used to hand down any sentences. However, in Ukraine as a whole just over 1,000 sentences were handed down on the basis of this qualification.

That being said, no conviction was appealed to the Court of Appeals and no one was subjected to remand in custody as a preventive measure during the pre-trial investigation, and thus no custodial sentences were handed down. Besides, during the investigation of the above-mentioned crimes and the cases referred to the District Court of Kryvyi Rih in Dnipropetrovsk region; no police officer or government official had become mentioned there; although it is objectively clear that to commit the crimes related to the illegal extraction of minerals of national impor- 
tance quickly and unnoticed without the support or help of law enforcement officers and officials appears more than doubtful.

Article 240, Paragraph 2 of the Criminal Code of Ukraine does not stipulate the confiscation of the crime instrumentalities inter alia the technical equipment) used for illegal extraction or transportation of minerals of state significance. It has nullified the financial risks of the individuals who illegally extract such minerals; on the contrary, the possible profits and damage caused to both an environment and a real sector of the economy are extremely high, creating a percentage of latency close to $100 \%$. In such cases not only the illegal extraction of the minerals of public importance but also the providing transportation services (even if they do not participate in extraction) should be criminalized. The status of such persons should be equated with "accomplices", which would also have positive consequences for the protection of public interests. It may be appropriate to criminalize the activities of those who will buy or sell illegally mined minerals of course if the persons have known or suspected the origin of the minerals. We have analyzed the total number of convictions under Article 240, Paragraph 2, of the Criminal Code of Ukraine in the regions over a period of 2005-2020; the results are shown in the Table.

More profound analysis of the sentencing decisions (the verdict in the case No. 177/2183/13-k dated 13 September 2013, No. 177/2344/14-k dated 19 August 2014, No. 177/2178/15-k dated 10 March 2016, No. 212/1065/17-k dated 16 March 2017) has revealed that almost in all the cases the individuals brought to justice, confess themselves guilty, express sincere remorse and, having received a suspended minimum sentence unrelated to the actual deprivation of liberty, do not even challenge such sentences.

Among the sentences that can be handed down by the District Court of Kryvyi Rih in Dnipropetrovsk region, in only one case, there was established not only the amount of direct damage caused by the person being prosecuted but also the amount of degraded land and illegally extracted minerals (case No. 177/1728/13-k dated 06 September 2013) [16]; whereas it had been made possible by the information received from the enterprise legally engaged in the development of the deposit of kaolin clay for several years. In connection with this case, as a consequence, five years of illegal mining within the Pavlivske field (the District of Kryvyi Rih in Dnipropetrovsk region) had resulted in the illegitimate extraction of more than twentyseven thousand square meters of the moulding sand and destruction of above two and a half thousand square meters of fertile ground soil. The official permission for the mining was issued only in late 2020. However, this situation is an exception and only confirms the real absence of an effective mechanism to bring illegal miners to criminal responsibility.

Table

Number of Convictions under Article 240, Paragraph 2, of the Criminal Code of Ukraine by regions for the period of 2005-2020

\begin{tabular}{|l|c|}
\hline \multicolumn{1}{|c|}{ Regions } & Number of Convictions \\
\hline $\begin{array}{l}\text { the District of Kryvyi Rih } \\
\text { (Dnipropetrovsk region) }\end{array}$ & 9 \\
\hline Dnipropetrovsk Region & 16 \\
\hline Zakarpatska Region & 25 \\
\hline Lviv Region & 36 \\
\hline Ivano-Frankivsk Region & 112 \\
\hline Kharkiv Region & 4 \\
\hline Poltava Region & 4 \\
\hline ARC & 3 \\
\hline Ukraine (verdict of first instance) & 1145 \\
\hline
\end{tabular}

Therefore, it is difficult not to agree with Professor Beschastnyi's opinion, who concluded in one of his works that "one of the main factors in the rapid development of the society is science. It must be ahead of practice and seek new ways to improve legal, economic, scientific, technical and social progress since the science begins not with facts but with the problems and methods for solving them" [17].

Taking into account the specifics of the study and the information provided, it is reasonable and necessary to carry out further improvement of the subsoil legal framework, which is substantially out of date and does not correspond to presentday realities, both the underground and open-pit mining of mineral resources (hydrocarbon extraction).

It is necessary to realize and recognize that the system of the subsoil use legislation requires fundamental readjustments, extensive studies that should lead to the formulation of the position on future integrated minerals regulations, which in turn will be harmonized with other parts of the legislation.

Thus it is expedient to support R.S. Kirin's position in the context of "formation of the Mineral Resources Code (MRC) which should be based on the contents of codified acts of mining, geological and underground legislation; that will be drafted in the form of the relevant laws and codes of MRC" [18]. In carrying out such codification, it will be quite possible to build new subsoil legislation on the basis of the codification of the Minerals Regulations with the adoption of the appropriate natural resources code "the Code of Ukraine about Subsoil" and its integration into the Environmental Code of Ukraine.

The review shows that the accountability for illegal exploitation of natural resources is multidimensional point and can be manifested in different spheres of social regulations. This paper attempts to highlight only certain aspects of the problem. It should, nevertheless, be noted that there could be delinquencies (offences, crimes) of labor relations, the offences in the field of mining and environmental standards even proceeding in extraction the mineral resources legally. All of the aforementioned makes the scholars of various spheres move in a forward direction first because the legislature is not able to enact the law and improve the current mechanisms without balanced and reasonable justification. On the other hand, this will have extremely negative consequences and will only increase the quantity and quality of the problems and their negative effects on all sectors. A number of scientific studies are devoted to the legal issues of hydrocarbon extraction. However, the topic is so significant and not typical for the industrial region of Kryvyi Rih that the amount of work does not allow it to be considered compared to problems of prosecution for illegal mining (including open-pit mining). In a similar vein, it is worth noting that from the $20^{\text {th }}$ century in the USA and EU there is a concept of protection of "critical infrastructure" linked to the legal enforcement of both the protection of the subsoil (primarily hydrocarbons) and the general security strategy of States.

Thus, the critical infrastructure is considered to involve "systems and facilities, physical or virtual, so vital and essential to the State that the incapacity or destruction of such systems or facilities undermines national security, the economy, public health or safety or results in any combination of the above".

Conclusions. The study has examined the rules governing the criminal liability for violations of the regulations of conservation of mineral resources, to wit the violation of the established rules related to exploitation of mineral resources if it has created a threat to life, human health or the environment, as well as illegal extraction of minerals of the public importance and their conformity with prerequisites for the criminalization of such activities, the effectiveness of these standards specifically to terminate the Illegitimate activities of the subsoil users as well as the preventive effectiveness of such standards and regulations; their being coherent with the challenges of the present era; the problematic issues of their 
effective application and the authors' position on supplementing existing legislation with more efficient mechanisms. The most obvious finding to emerge from this study is that illegal extraction of mineral resources of state significance does not correspond to the specified condition covered by Article 240 of the Criminal Code of Ukraine. It should be improved through further development, explicitation and specification of the actions by illegal miners. The authors' position is that it is necessary to develop the regulation that enables us to classify the constituent elements of the crime as material ones; to conduct the mandatory research during the pre-trial investigation of the amount of damage caused by the crime and to determine the proportion of the specific mineral deposits by means of the land-use planning (other technical measures), which in turn will make it possible to obtain information on the area of degraded land and the quantity of illegally extracted minerals, the destruction of forests stands and damage to water bodies.

In the light of actual case law in the District Court of Kryvyi Rih in Dnipropetrovsk region [19, 20], the authors have proven practicability of supplementing the description of Article 240 of the Criminal Code of Ukraine with qualifying characteristic such as the commission of an offence by a group of persons (inter alia, by prior conspiracy). The authors also suggest adding to the penal part of the Article the enhancement of the possible penalties through the confiscation of the equipment and means of transport by which minerals of national importance were extracted illegally regardless of the volumes of extraction. In this instance, paragraph 2 of Article 240 of the Criminal Code of Ukraine should accordingly be amended as follows: "Violation of the established rules of subsoil use, if it has created a threat to life, human health or the environment, as well as illegal extraction of minerals of state significance by a group of persons or an organized group of persons, is sentenced to a fine of between three and five thousand times the personal income-tax allowance, or to up to three years in prison or custodial restraint with the confiscation of the technical equipment, that was used for illegal extraction of minerals of state significance (inter alia vehicles, special, rail transport, and others)".

In addition, taking into account the analysis of the jurisprudence of the District Court of Kryvyi Rih in Dnipropetrovsk region, the authors have proven the relevance to amend other legal and regulatory instruments; whereby the local authorities, when receiving the information on the initiation of legal proceedings under Article 240 of the Criminal Code of Ukraine, must assume responsibility for monitoring the corresponding deposit, to carry out land-use surveys to measure the area of the object (within the local budget), to make onsite inspections with mandatory photo-recording of the site at least once a month. To implement this mechanism effectively, the law enforcement agencies, conducting pre-trial investigations of relevant crimes and making regular entries the Unified Register of Pre-trial Investigations, should mandatorily report about the initiation of the pre-trial investigation to the local government where there is a fact (facts) of illicit extraction of mineral resources. Under the circumstances, regardless of the terms of pre-trial investigation, whether there are convictions or whether there are acquittals, the people of Ukraine represented in the local government body will be enabled to fix the legal facts with a view to getting the information effectively as for the certain deposit in general as well as to calculate the amount of damage via the expert studies, where similar crimes are committed in the future. But in case the gaps in the current legislation and inefficient work of law enforcement agencies remain unchanged, it might result in extremely poor judicial performance when, in fact, the case ends with a conviction, but the sanction imposed by the court is utterly small, so the preventive function is not fulfilled.

It might be prudent to grant a victim status in criminal proceedings on illegal extraction of mineral resources to the territorial communities on whose territory the crime has been committed.

Having regard to the profit motive of all crimes related to illegal mining and compulsory using of special equipment for excavation and transportation, it is appropriate to develop and implement a fast and efficient seizure procedure for industrial equipment, mechanical-transport equipment (tracks, shovels), and prohibit the re-registration of such equipment to other owners by the time the investigation is completed but without the right to withdraw the equipment from the owner; otherwise, it could encourage corrupt relationships between law enforcement and other individuals as well as the manipulation of the law against law-abiding subsoil users.

However, to eliminate the preconditions for, or at least minimize, the risks of illegal mining, taking into account available scientific research in the fields of subsoil use, mining, environmental law and mineral resources law, we also consider it necessary to conduct a comprehensive codification of minerals regulations and adopt the Environmental Code of Ukraine.

Providing the role of local self-government is strengthened as representatives of the real owner that is the people of Ukraine in a certain sense, protection against "unfair competition" of subsoil users who carry out the activities within the framework of existing legislation is also enhanced, the State of Ukraine will be able to strengthen cooperation with the EU in the field of environmental protection, and to adapt minerals regulations and environmental legislation to EU standards.

Such a comprehensive approach significantly enhances not only the effectiveness of criminal liability in the case of illegal mining but also the remarkable effectiveness of preventive action while minimizing the risks of corrupt activities among individuals who are engaged in illegal mining of minerals, the representatives of law enforcement bodies, government institutions, and local authorities taking on board international experience with the judicial defense of citizens' environmental rights.

\section{References.}

1. Verkhovna Rada of Ukraine (n.d.). Constitution of Ukraine; Law of Ukraine dated 28.06.1996 No. 254k/96-VR. Retrieved from https://zakon.rada.gov.ua/laws/show/254\%D0\%BA/96$\% \mathrm{D} 0 \% \mathrm{~B} 2 \% \mathrm{D} 1 \% 802$.

2. Trofimchuk, O.M., Korzhniev, M.M., Yakovliev, Y.O., Kurylo, M. M., \& Kosharna, S. K. (2018). Conceptual approaches to organization of monitoring of geological environment and mineral resources of Ukraine in modern terms. Environmental safety and natural resources, 4(28), 7-26.

3. Pietkov, S. V. (Ed.). (2017). Scientific and practical commentary on the Code of Administrative Procedure: as of January, 17, 2017. Kyiv. Retrieved from http://dspace.univd.edu.ua/xmlui/bitstream/hand $1 \mathrm{e} / 123456789 / 7757 / \mathrm{komentar} 2017$. pdf? sequence $=1 \&$ amp;isAllowed $=\mathrm{y}$.

4. Marych, K. (2018). Objective and tasks of administrative and legal security mechanism of providing environmental safety in Ukraine. Entrepreneurship, Economy and Law, 10, 118-121.

5. Stelmakh, M. V. (2017). The issue of classification of illegal extraction of mineral resources of local relevance. Young Scientist, 12(52), 323-327.

6. Marych, K. (2019). Correlation of the state environmental policy and environmental legislation of Ukraine. Entrepreneurship, Economy and Law, 11, 187-191. https://doi.org/10.32849/2663-5313/2019.11.32. 7. Krasnova, Yu. A. (2020). Legal environmental safety in the European Union. South Ukrainian Law Journal, (2), 70-71.

8. Karakash, I.I. (Ed.). (2019). Pryrodnoresursovi kodeksy Ukrainy: Vodnyi, Zemelnyi i Lisovyi kodeks Ukrainy ta Kodeks Ukrainy pro nadra ( $2^{\text {nd }}$ ed.). Odesa. Retrieved from https://hdl.handle.net/11300/12452. 9. Hetman, A. P. (2020). The legal foundations of the EU $7^{\text {th }}$ environmental program $\left(7^{\text {th }} \mathrm{EP}\right)$ on the protection, conservation and improvement of natural resources. Economic Theory and Law, 1(40), 98112. https://doi.org/10.31359/2411-5584-2020-40-1-98.

10. Andrieiev, A. (2019). The mechanism of legal regulation of social relations: certain aspects of defining the concept and peculiarities. $E n-$ trepreneurship, Economy and Law, 6, 125-128. https://doi.org/10.3284 9/26635313/2019.6.22. 
11. Sirant, M. M. (2020). Features of administrative and legal guarantees of realization of the right to a favorable natural environment. Pravovi Novely, 2(10), 77-84. https://doi.org/10.32847//n.2020.10-2.10. 12. Verkhovna Rada of Ukraine (n.d.). The Criminal Code of Ukraine (Vol. 25-26, p. 131). Retrieved from https://zakon.rada.gov.ua/laws/ show/2341-14\#Text.

13. Interfax-Ukraine. Ukraine News Agency (2020, November 8). Prosecutor Bohdan Zarichanskyi on responsibility for violating the rules of protection or use of underground resources [Press release]. Retrieved from https://ua.interfax.com.ua/news/press-release/704221.html. 14. Democracy Reporting International, Prepared by Natalia Dryomina-Voloc (2019, January 30). Reforming the Public Prosecutor's office of Ukraine: Institutional aspect [Press release]. Retrieved from https:// democracy-reporting.org/wp-content/uploads/2019/01/DRI-UABP-Prosecution-Institutional-Reform.pdf.

15. David, R. (2016). Prospects of the court. reforms: analysis of the survey of judges of Ukraine. USAID. Retrieved from https://newjustice.org.ua/wp-content/uploads/2018/06/FAIR_Report_Roman David Judges Survey 2016 UKR.pdf.

16. Unified Register of Pre-Trial Investigations (2013). Crimes against the environment; Violation of the rules of protection or use of subsoil, No. 177/1728/13-K. Retrieved from https://reyestr.court.gov.ua/Review/33535396.

17. Beschastnyi, V. M. (2017). Criminological support of crime prevention in Ukraine: monograph. Kharkiv, Ukraine.

18. Kirin, R. S. (2018). Subject of law of protection about the bowels of the earth. Economics and Law, 3, 38-48. https://doi.org/10.15407/ econlaw.2018.03.038

19. Unified Register of Pre-Trial Investigations (2015). Crimes against the environment; Violation of the rules of protection or use of subsoil. No. 177/2499/15-K. Retrieved from https://reyestr.court.gov.ua/Review/53822857.

20. Unified Register of Pre-Trial Investigations (2013). Crimes against the environment; Violation of the rules of protection or use of subsoil. No.177/2183/13-K. Retrieved from https://reyestr.court.gov.ua/Review/33515126.

\section{Проблемні питання притягнення до кримінальної відповідальності за незаконний видобуток корисних копалин}

\section{О. Ю. Макаренко ${ }^{1}$, Н. А. Макаренко ${ }^{1}$ О. В. Назимко ${ }^{2}$, Ю. О. Громенко ${ }^{3}$, К. О. Нестеренко ${ }^{1}$}

1 - Донецький юридичний інститут МВС України, м. Кривий Ріг, Україна, e-mail: a.y.makarenko@gmail.com 2 - Східноукраїнський національний університет імені Володимира Даля, м. Сєвєродонецьк, Україна

3 - Одеський державний університет внутрішніх справ, м. Одеса, Україна

Мета. Дослідження криміналізації посягань, пов'язаних із незаконним видобутком корисних копалин загальнодержавного значення, що є важливим як для законотворчої, так і правозастосовчої діяльності. Розробка про- позицій для формування й реалізації програм економічного розвитку, удосконалення ефективності роботи органів державної влади й місцевого самоврядування.

Методика. Дослідження проблемних питань притягнення до відповідальності за незаконний видобуток корисних копалин проводилося шляхом вивчення та аналізу нормативно-правової бази України, теоретичних досліджень учених у відповідних областях, аналізу судової практики (на прикладі окремих вироків) з питань притягнення осіб до кримінальної відповідальності за ч. 2 ст. 240 Кримінального кодексу України, а також з використанням системи спеціальних підходів і методів, а саме формально-логічного, логіко-нормативного, методу системного аналізу.

Результати. Виявлені окремі проблеми, шо виникають при формуванні кримінально-правової заборони досліджуваних кримінальних практик на законодавчому рівні, у тому числі невідповідність криміналізації незаконного видобутку корисних копалин ступеню тяжкості негативних правових наслідків.

Наукова новизна. У роботі проаналізовані проблемні питання притягнення до відповідальності за незаконний видобуток корисних копалин за ч. 2 ст. 240 Кримінального кодексу України «Порушення встановлених правил використання надр, якщо це створило загрозу для життя, здоров'я людей або довкілля, так само незаконний видобуток корисних копалин загальнодержавного значення». Обгрунтовані пропозиції, що спрямовані на вдосконалення чинного кримінального законодавства та практики його застосування правоохоронними органами України у сфері протидії незаконному видобутку корисних копалин загальнодержавного значення.

Практична значимість. У роботі досліджені норми, що встановлюють відповідальність за незаконний видобуток корисних копалин, а також судова практика правозастосування вказаних норм. Зроблено висновок, що незаконний видобуток корисних копалин загальнодержавного значення на сьогоднішній день фактично залишається безкарним. Аргументована авторська позиція щодо доцільності вдосконалення норми кримінального законодавства, що передбачає відповідальність за вказане діяння, з більш чітким формулюванням диспозиції та розширення й посиленням санкції за ч. 2 ст. 240 Кримінального кодексу України. Доведена доцільність розширення кола суб'єктів за вказаною статтею, з огляду на залучення широкого кола осіб як безпосередньо у процес незаконного видобутку корисних копалин, так і подальшого транспортування та реалізації.

Ключові слова: корисні копалини, видобуток, відповідальність, кримінальний кодекс України, санкція, диспозиція, правоохоронні органи, органи місцевого самоврядування

Recommended for publication by O. O. Krasnorutsky, Doctor of Economic Sciences. The manuscript was submitted 18.12.20. 